Note

\title{
Spoilage Ability of Psychrotrophic Paenibacillus spp. Isolated from Cooked Food Products
}

\author{
YOSHIKATSU HAMASAKI, SATOSHI KOTOURA*, \\ MASATO NAKANE, AND MASAAKI SUGIYAMA
}

\author{
Central Research Institute, Marudai Food Co., Ltd., 21-3, \\ Midori-cho, Takatsuki, Osaka 569-8577, Japan
}

Received 26 May 2005/Accepted 24 August 2005

\begin{abstract}
Five spore-forming bacterial strains were isolated as the most dominant microorganisms from five products of different types of cooked food. Three strains in particular were isolated as spoilage organisms causing acidity. These belonged to the genus Paenibacillus, and one of them was identified as Paenibacillus odorifer. All five strains grew at $10^{\circ} \mathrm{C}$ in brain heart infusion broth; furthermore, four strains grew at $4^{\circ} \mathrm{C}$ also. These strains grew optimally at 30 to $35^{\circ} \mathrm{C}$. Psychrotrophic Paenibacillus spp. can easily be mistaken for lactic acid bacteria in routine analysis because of their colony characteristics. Because the measures that must be taken for bacterial control are different in the case of contamination by these two bacterial groups, psychrotrophic Paenibacillus spp. contamination must be distinguished from that caused by lactic acid bacteria.
\end{abstract}

Key words : Psychrotrophic Paenibacillus spp./Spoiling ability/Lactic acid bacteria.

One of the theories in the food industry is that cooked food products can be preserved by distributing and selling them at low temperatures. By this method, most vegetative cells are destroyed by the cooking process, and the surviving spore-forming microorganisms are inhibited from growing by the cool temperatures. Therefore, with hygienic handling of the cooked products for avoidance of crosscontamination, these products have a long shelf-life.

However, this treatment typically raises opportunities for the growth of psychrotrophic spore-forming bacteria like Bacillus cereus, Bacillus thuringiensis, Bacillus mycoides (Francis et al., 1998) and nonproteolytic Clostridium botulinum (Juneja et al., 1995), which may survive the heat treatment and grow at low temperatures. Because it is difficult to control these bacteria, contamination by them is a serious problem in the food industry. The behavior of psychrotrophic Bacillus spp. and Clostridium spp. in food spoilage have been studied thoroughly (Jaquette and Beuchat, 1998; Kalinowski and

${ }^{*}$ Corresponding author. Tel: +81-72-661-2552, Fax : +8172-661-2598.
Tompkin, 1999), but there is little known about the behavior of other psychrotrophic spore-forming bacteria.

Paenibacillus spp. are gram-positive and sporeforming rods belonging to a class of bacilli of the phylum Firmicutes, formerly belonging to the genus Bacillus (Ash et al., 1993; Boone and Castenholtz, 2001). These bacteria have been isolated from a variety of sources, including soil, water and plants, and often contaminate foods (Bosshard et al., 2002). However, little is known about the spoilage behavior of Paenibacillus spp. In this study, we investigated the spoilage ability of Paenibacillus spp. in cooked food products at low temperatures.

Five samples of commercially available food products were obtained; two scotch eggs and two omelets individually packed by modified-atmosphere packaging, and a milk tea dessert containing tapioca pearls in a plastic cup. These samples were diluted 10-fold with a sterile $0.85 \% \mathrm{NaCl}$ solution and treated with a stomacher (Pro-media SH-001; Elmex Ltd., Tokyo, Japan) for $1 \mathrm{~min}$, and serial dilutions were then prepared. Bacterial counts were determined by the standard plate count (SPC) technique. 
Colonies from the SPC plates were selected at random and cultured on Brain Heart Infusion (BHI) agar (Oxoid Ltd., Basingstoke, Hampshire, UK) for $48 \mathrm{~h}$ at $30^{\circ} \mathrm{C}$. BHI agar plates with the pure culture were used for Gram staining, catalase testing, oxidase testing, and morphology testing. Each pure culture was further characterized by $16 \mathrm{~S}$ rDNA analysis and biochemical tests. A 500-bp fragment of the 16S rRNA gene was amplified from genomic DNA from each isolate by $\mathrm{PCR}$, and sequenced using the reagents and protocol supplied in the MicroSeq 500 bacterial sequencing kit (Applied Biosystems, Foster City, CA, USA). The BLAST program was used to compare the present 16S rDNA sequences with sequences deposited in the GenBank (http://www.ncbi.nlm.nih.gov/) and DDBJ (http://www.ddbj.nig.ac.jp/) databases. For phylogenetic analysis, the sequences were aligned, neighbour-joining trees were constructed using ClustalX (version 1.81) (Thompson et al., 1997), and then the tree was edited using the TreeView program (version 1.6.6) (Page, 1996). The DDBJ accession numbers for the $16 \mathrm{~S}$ rDNA sequences of strain MCRI 9, 11, 90, 122, and 337 are AB210069, $A B 210070, A B 210071, A B 210072$ and AB210073, respectively. Biochemical tests were performed by using the API $20 \mathrm{E}$ and $\mathrm{API} 50 \mathrm{CHB}$ systems (bioMerieux, Marcy-l'Etoile, France).

Growth curves at low temperatures were based on cell numbers in the $\mathrm{BHI}$ broth. Precultures of the strains were prepared by incubation in the $\mathrm{BHI}$ broth (Oxoid) for $24 \mathrm{~h}$ at $30^{\circ} \mathrm{C}$. The cells were washed with sterile $0.85 \% \mathrm{NaCl}$ solution and diluted to approximately $10^{4} \mathrm{CFU} / \mathrm{ml} .100 \mu \mathrm{l}$ of the cell suspensions were added into $10 \mathrm{ml}$ of pre-cooled $\mathrm{BHI}$ broth and incubated at 10 or $4^{\circ} \mathrm{C}$. The cell numbers were determined by plate counting with $\mathrm{BHI}$ agar. Growth curves at mesophilic temperatures were based on optical density in the $\mathrm{BHI}$ broth. Precultures $(1 \mathrm{ml})$ were added into the $\mathrm{BHI}$ broth $(100 \mathrm{ml})$ and incubated at $25 \pm 0.2,30 \pm 0.2,35 \pm 0.2,37 \pm 0.2,39 \pm 0.2$, or $40 \pm 0.2^{\circ} \mathrm{C}$ in a water bath (Personal-11; TAITEC Co., Ltd., Saitama, Japan). Optical density was measured with absorbance at $660 \mathrm{~nm}$.

Large numbers of bacteria were detected in the five food samples (Table 1). In particular, the two scotch

TABLE 1. Bacterial counts of products

\begin{tabular}{lcc}
\hline \multicolumn{1}{c}{ Products } & $\begin{array}{r}\text { Period preserved } \\
\text { at } 10^{\circ} \mathrm{C} \text { (days) }\end{array}$ & SPC (CFU/g) \\
\hline Scotch egg A & 14 & $>10^{7}$ \\
Scotch egg B & 14 & $>10^{7}$ \\
Omelet A & 17 & $1.4 \times 10^{5}$ \\
Omelet B & 15 & $9.6 \times 10^{5}$ \\
Milk tea dessert & 35 & $>10^{7}$ \\
\hline
\end{tabular}

eggs and milk tea dessert had soured, and contained bacteria of over $10^{7} \mathrm{CFU} / \mathrm{g}$. The scotch eggs and milk tea dessert had been kept for 14 and 35 days, respectively, at $10^{\circ} \mathrm{C}$. In the two omelets, spoilage did not occur, but $10^{5} \mathrm{CFU} / \mathrm{g}$ levels of bacteria were detected. Omelets $A$ and $B$ had been kept for 17 and 15 days, respectively, at $10^{\circ} \mathrm{C}$. Several dominant organisms were isolated from each plate with the highest dilution, and five strains, MCRI 9 (culture collection of Marudai Central Research Institute), 11, 90, 122 and 337 were isolated as the most dominant organisms from the Scotch eggs $A$ and $B$, Omelets $A$ and $B$, and the milk tea dessert, respectively.

All isolates were gram positive, catalase positive,

TABLE 2. Phenotypic characteristics of isolates from products, and those of Paenibacillus amylolyticus and Paenibacillus odorifer.

\begin{tabular}{|c|c|c|c|c|c|c|c|}
\hline & 1 & 2 & 3 & 4 & 5 & 6 & 7 \\
\hline Anaerobic growth & + & + & + & + & + & + & + \\
\hline Oxidase & - & - & - & + & - & - & - \\
\hline Gelatin hydrolysis & + & - & - & + & - & + & NR \\
\hline Nitrate reduction & + & + & - & - & - & + & + \\
\hline \multicolumn{8}{|l|}{ Acid from: } \\
\hline Glycerol & + & + & + & + & - & + & v \\
\hline D-Arabinose & - & - & - & - & - & NR & - \\
\hline L-Arabinose & + & + & + & + & + & + & + \\
\hline Ribose & + & + & + & + & - & + & + \\
\hline D-Xylose & + & + & + & + & + & + & + \\
\hline Adonitol & - & - & - & - & - & - & - \\
\hline$\beta$ Methyl D-xyloside & + & + & + & + & + & NR & + \\
\hline Galactose & + & + & + & + & + & + & + \\
\hline Fructose & + & + & + & + & + & + & + \\
\hline Mannose & + & - & + & + & + & + & v \\
\hline Sorbose & - & - & - & - & - & - & - \\
\hline Rhamnose & - & - & - & - & - & - & - \\
\hline Inositol & - & - & - & - & - & + & - \\
\hline Mannitol & + & - & - & + & + & + & - \\
\hline Sorbitol & - & - & - & - & - & - & - \\
\hline$\alpha$-Methyl-D glucoside & - & + & + & + & + & NR & + \\
\hline Salicin & + & + & + & + & + & + & + \\
\hline Cellobiose & + & + & + & + & + & + & + \\
\hline Maltose & + & + & + & + & + & + & + \\
\hline Lactose & + & + & + & + & + & - & + \\
\hline Melibiose & + & + & + & + & + & + & + \\
\hline Sucrose & + & + & + & + & + & + & + \\
\hline Trehalose & + & + & + & + & + & + & + \\
\hline Inulin & - & + & + & - & - & + & + \\
\hline Melezitose & - & - & + & - & + & NR & - \\
\hline Raffinose & + & + & + & + & + & - & + \\
\hline Starch & + & + & + & + & - & + & + \\
\hline
\end{tabular}

Strains: 1, Paenibacillus sp. MCRI 9; 2, P. odorifer MCRI 11; 3, Paenibacillus sp. MCRI 90; 4, Paenibacillus sp. MCRI 122; 5, Paenibacillus sp. MCRI 337; 6, P. amylolyticus (Shida et al., 1997); 7, P. odorifer (Berge et al., 2002). +, positive reaction; - , negative reaction; $v$, variable reaction; $\mathrm{NR}$, not reported. 
and spore forming rods. In strain MCRI 11, BLAST analysis of the $16 \mathrm{~S}$ rDNA sequence showed similarity with that of Paenibacillus odorifer, with identity of over $99 \%$ to $P$. odorifer TOD $45^{\top}$ (accession number AJ223990) without single nucleotide polymorphisms. The biochemical properties of strain MCRI 11 were consistent with those of $P$. odorifer according to biochemical tests using the API systems (Table 2) (Berge et al., 2002). Therefore, strain MCRI 11 was identified as $P$. odorifer. The $16 \mathrm{~S}$ rDNA sequences of strains MCRI 9 and 122 showed identity of over $99 \%$ to Paenibacillus amylolyticus NRRL NRS-290 ${ }^{\top}$ (accession number D85396) without single nucleotide polymorphisms. However, their biochemical properties were not consistent with those of $P$. amylolyticus, because acid production from lactose and raffinose was positive and from inositol and inulin was negative (Shida et al., 1997). Thus, strains MCRI 9 and 122 were not identified as species in this study. The $16 \mathrm{~S}$

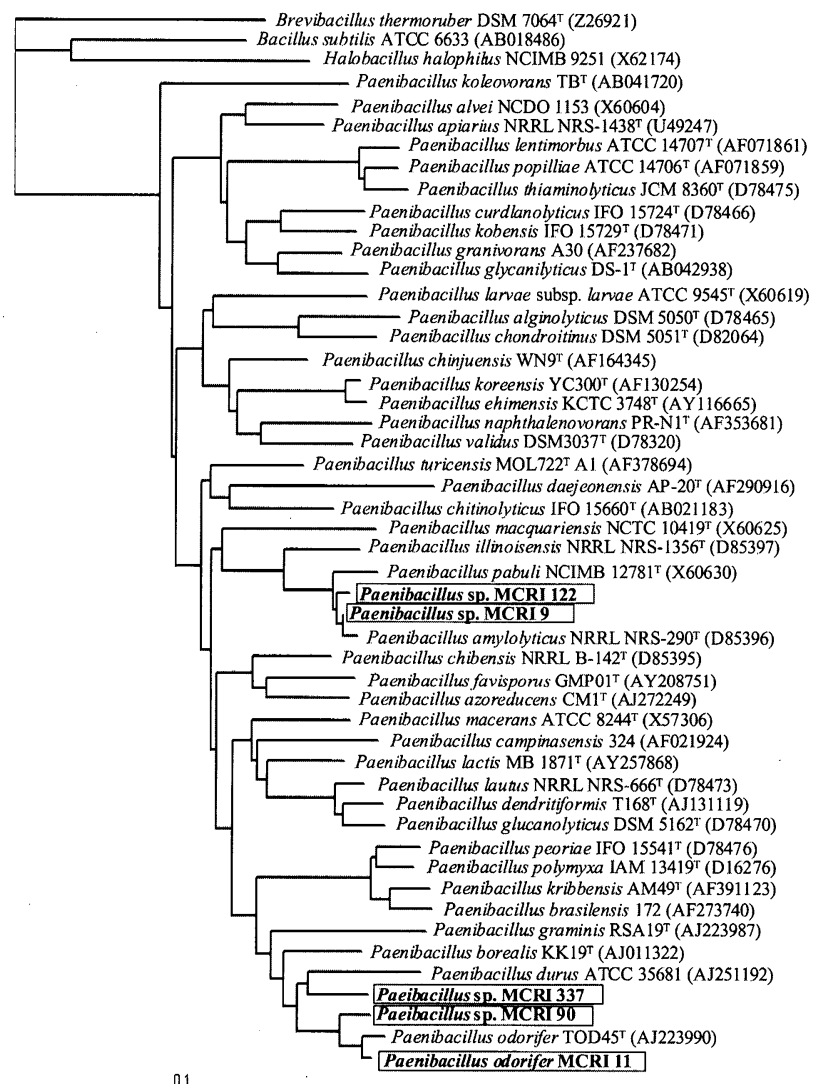

FIG. 1. Phylogenetic relationship of five strains, MCRI 9, 11, 90, 122 and 337, to the published Paenibacillus species and some other aerobic, rod-shaped, endosporeforming bacteria based on $16 \mathrm{~S}$ rDNA sequences. The branching pattern was generated by the neighbour-joining method. A total of approximately 500 bases between positions 5 and 531 ( $E$. coli numbering) were used for this analysis. Sequence accession numbers are in parentheses. Bar, 0.1 nucleotide substitutions per site.
rDNA sequences of strains MCRI 90 and 337 showed identity of under $97 \%$ to all other bacteria identified for species in databases, showing similarity with that of Paenibacillus spp. According to the phylogenetic analysis results, it was confirmed that strains MCRI 9 , 90, 122 and 337 belong to genus Paenibacillus (Fig. 1).

These five Paenibacillus strains grew at $10^{\circ} \mathrm{C}$ in $\mathrm{BHI}$ broth (Fig. 2A). Four strains in particular, MCRI 9, 11, 90 and 122, grew rapidly; the initial cell numbers of $10^{2} \mathrm{CFU} / \mathrm{ml}$ level increased to over $10^{7}$ $\mathrm{CFU} / \mathrm{ml}$ in 6 days. Furthermore, these four strains grew at $4^{\circ} \mathrm{C}$, while Paenibacillus sp. MCRI 337 did not grow (Fig. 2B). Three strains, MCRI 9, 11 and 90, tended to grow rapidly at $4^{\circ} \mathrm{C}$; they increased to $10^{7}$ $\mathrm{CFU} / \mathrm{ml}$ over 20 days. Four strains excluding Paenibacillus sp. MCRI 337 grew optimally at 30 to $35^{\circ} \mathrm{C}$ (Fig. 3). The maximum growth temperatures of Paenibacillus sp. MCRI 9, 90 and P. odorifer MCRI 11 were 37 to $39^{\circ} \mathrm{C}$ (Figs. 3A-C). Paenibacillus sp. MCRI 122 tended to grow at a higher temperature, and its maximum temperature for growth was $40^{\circ} \mathrm{C}$ (Fig. 3D) because this strain did not grow at $42^{\circ} \mathrm{C}$ (data not shown). In the growth of Paenibacillus sp. MCRI 337, its optimum and maximum temperatures were approximately 30 and $35^{\circ} \mathrm{C}$, respectively (Fig. $3 \mathrm{E}$ ).

Generally, because cooked food products are produced with good quality ingredients contaminated by a small quantity of microorganisms, the initial bacterial counts are very small, below $10 \mathrm{CFU} / \mathrm{g}$ in most cases. Nevertheless, Paenibacillus sp. MCRI 9, P. odorifer MCRI 11 and Paenibacillus sp. MCRI 337 were isolated as spoilage organisms causing acidity due to their growth property at low temperatures. Although Paenibacillus sp. MCRI 90 and 122 did not spoil the foods we tested, it is believed that they also possess spoilage ability. These bacteria are considered to mainly originate from plant materials.

Paenibacillus spp. formed pinpoint colonies on SPC agar or Plate Count Agar with Bromocresol
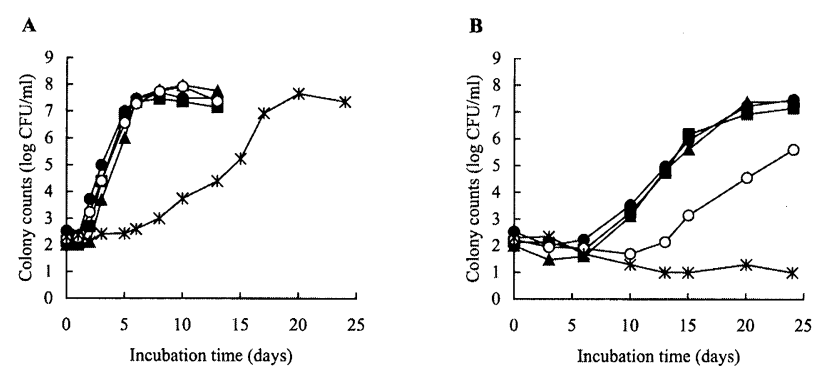

FIG. 2. Growth curves of Paenibacillus sp. MCRI 9 (O), Paenibacillus odorifer MCRI 11 ( $\mathbf{A}$ ), Paenibacillus sp. MCRI 90 (ם), Penibacillus sp. MCRI 122 (O) and Paenibacillus sp. MCRI $337\left(^{*}\right)$ in $\mathrm{BHI}$ broth at $10^{\circ} \mathrm{C}(\mathrm{A})$ and $4^{\circ} \mathrm{C}(\mathrm{B})$. 
$\mathbf{A}$

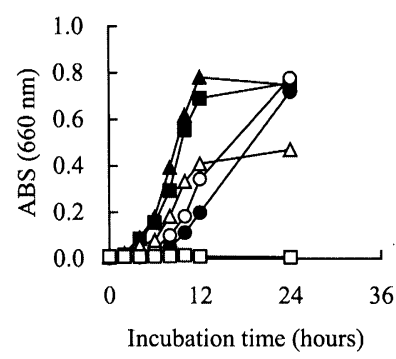

C

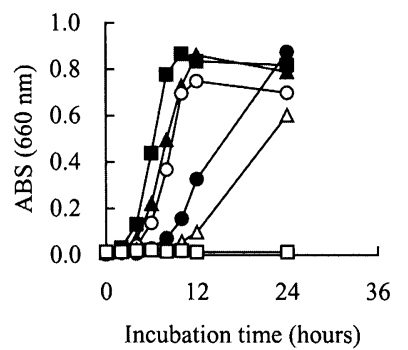

$\mathrm{E}$

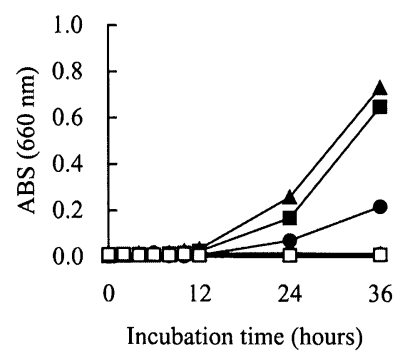

FIG. 3. Growth curves of Paenibacillus sp. MCRI 9 (A), Paenibacillus odorifer MCRI 11 (B), Paenibacillus sp. MCRI 90 (C), Penibacillus sp. MCRI 122 (D) and Paenibacillus sp. MCRI 337 (E) in $\mathrm{BHI}$ broth at $25^{\circ} \mathrm{C}(\mathrm{O})$, $30^{\circ} \mathrm{C}(\boldsymbol{\Delta}), 35^{\circ} \mathrm{C}(\boldsymbol{\square}), 37^{\circ} \mathrm{C}(\mathrm{O}), 39^{\circ} \mathrm{C}(\triangle)$ and $40^{\circ} \mathrm{C}$ $(\square)$.

Purple (PCABP) like lactic acid bacteria (data not shown). Paenibacillus spp. in particular form colonies accompanied by a yellow halo on PCABP, and it is therefore easy to mistake them for lactic acid bacteria in routine bacterial analysis. Lactic acid bacterial contamination in cooked foods is almost always caused by cross-contamination after cooking because lactic acid bacteria have low heat tolerance (Hamasaki et al., 2003) while Paenibacillus spp., originating from ingredients, survive during the cooking process and then contaminate foods. Because the measures that must be taken for bacterial control are different in the case of contamination by these two bacterial groups, contamination by Paenibacillus spp. must be distinguished from contamination by lactic acid bacteria. In routine analysis, catalase testing is a good method for distinguishing between these two groups; Paenibacillus spp. show positive results whereas lactic acid bacteria show negative results.
The heat tolerance of psychrotrophic spore-forming bacteria tends to be lower than those of other sporeforming bacteria. For example, non-proteolytic $C$. botulinum type $B$ and psychrotrophic $B$. cereus indicate D-values of 0.8 and 2.2-9.2 min, respectively, at $90^{\circ} \mathrm{C}$ (Juneja et al., 1995; Dufrenne et al., 1995). Furthermore, Paenibacillus polymyxa indicates the Dvalue of $1.3-7.7 \mathrm{~min}$ at $90^{\circ} \mathrm{C}$ in milk (Casadei et al., 2000). It is expected that retort sterilization is unnecessary to sterilize psychrotrophic spore-forming bacteria, but at least several minutes of heating at approximately $90^{\circ} \mathrm{C}$ are needed for destruction of these bacteria. In recent years, manufacturers have tended to avoid excessive heating during the cooking process, so as to preserve taste. Therefore, foods are being cooked for shorter amounts of time or at lower temperatures, and psychrotrophic spore-forming bacteria can easily survive in these cooked foods. If there is a risk of such bacterial contamination, manufacturers need to cook foods more thoroughly.

In conclusion, psychrotrophic Paenibacillus spp. were newly isolated as spore-forming bacteria which survive the cooking process, grow at low temperatures and then cause food spoilage. To preserve food, these must be controlled similarly to psychrotrophic Bacillus spp. and Clostridium spp. Because psychrotrophic Paenibacillus spp. can easily be mistaken for lactic acid bacteria in routine analysis, the person in charge of bacterial analysis should give proper attention to the presence of these bacteria.

\section{REFERENCES}

Ash, C., Priest, F. G., and Collins, M. D. (1993) Molecular identification of rRNA group 3 bacilli (Ash, Farrow, Wallbanks and Collins) using a PCR probe test. Proposal for the creation of a new genus Paenibacillus. Antonie Van Leeuwenhoek, 64, 253-260.

Berge, O., Guinebretiere, M. H., Achouak, W., Normand, P., and Heulin, T. (2002) Paenibacillus graminis sp. nov. and Paenibacillus odorifer sp. nov., isolated from plant roots, soil and food. Int. J. Syst. Evol. Microbiol., 52, 607-616.

Boone, D. R., and Castenholtz, R.W. (Eds.) (2001) Bergey's manual of systematic bacteriology, 2nd ed., vol. 1, Springer-Verlag, New York, N.Y.

Bosshard, P. P., Zbinden, R., and Altwegg, M. (2002) Paenibacillus turicensis sp. nov., a novel bacterium harbouring heterogeneities between 16S rRNA genes. Int. J. Syst. Evol. Microbiol., 52, 2241-2249.

Casadei, M. A., Ingram, R., Skinner, R. J., and Gaze, J. E. (2000) Heat resistance of Paenibacillus polymyxa in relation to $\mathrm{pH}$ and acidulants. J. Appl. Microbiol., 89, 801806.

Dufrenne, J., Bijwaard, M., te Giffel, M., Beumer, R., and Notermans, S. (1995) Characteristics of some 
psychrotrophic Bacillus cereus isolates. Int. J. Food Microbiol., 27, 175-183.

Francis, K. P., Mayr, R., von Stetten, F., Stewart, G. S., and Scherer, S. (1998) Discrimination of psychrotrophic and mesophilic strains of the Bacillus cereus group by PCR targeting of major cold shock protein genes. Appl. Environ. Microbiol., 64, 3525-3529.

Hamasaki, Y., Ayaki, M., Fuchu, H., Sugiyama, M., and Morita, H. (2003) Behavior of psychrotrophic lactic acid bacteria isolated from spoiling cooked meat products. Appl. Environ. Microbiol., 69, 3668-3671.

Jaquette, C. B., and Beuchat, L. R. (1998) Combined effects of $\mathrm{pH}$, nisin, and temperature on growth and survival of psychrotrophic Bacillus cereus. J. Food Prot., 61, 563-570.

Juneja, V. K., Eblen, B. S., Marmer, B. S., Williams, A. C., Palumbo, S. A., and Miller, A. J. (1995) Thermal resistance of nonproteolytic type $B$ and type $E$ Clostridium botulinum spores in phosphate buffer and turkey slurry. J. Food Prot., 58, 758-763

Kalinowski, R. M., and Tompkin, R. B. (1999) Psychrotrophic clostridia causing spoilage in cooked meat and poultry products. J. Food Prot., 62, 766-772.

Page, R. D. M. (1996) TREEVIEW: an application to display phylogenetic trees on personal computers. Comput. Appl. Biosci., 12, 357-358.

Shida, O., Takagi, H., Kadowaki, K., Nakamura, L. K., and Komagata, K. (1997) Emended description of Paenibacillus amylolyticus and description of Paenibacillus illinoisensis sp. nov. and Paenibacillus chibensis sp. nov. Int. J. Syst. Bacteriol., 47, 299-306.

Thompson, J. D., Gibson, T. J., Plewniak, F., Jeanmougin, F., and Higgins, D. G. (1997) The CLUSTAL_X windows interface: flexible strategies for multiple sequence alignment aided by quality analysis tools. Nucleic Acids Res., 25, 4876-4882. 